\title{
GURINDER CHADHA'S VICEROY'S HOUSE (2017) AND OTHER EVICTIONS: TRANSNATIONAL CONNECTIONS OF PAST AND PRESENT CRISES IN CINEMA
}

\author{
Elena Oliete-Aldea \\ Universidad de Zaragoza*
}

\begin{abstract}
Crisis is the word that seems to best characterize the twenty-first century conjuncture. The bleakness and instability of an uncertain and troubled present often encourages the proliferation of nostalgic images of past times, which become sweetened scenarios for escapist memories. On the other hand, the local and global current economic, social and political divisions have also brought to light the need to revisit certain aspects of the past from other perspectives. This is the case of Gurinder Chadha's films, which frequently advocate for the crossing of cultural borders by showing the hybrid nature of communities and their heritage. Following Robert Stam's cultural and filmic methodology which includes a transdisciplinary, transmediatic, transtextual, transregional, and transartistic approach (2019), I aim to analyze Chadha's Viceroy's House as a film that proposes a revision of India's Partition while offering a critical transnational and intersectional connection of contemporary global and local scenarios.
\end{abstract}

Keywords: Crisis, Recession, Heritage Film, Transnational, Nostalgia.

EL ÚLTIMO VIRREY DE LA INDIA (CHADHA 2017) Y OTROS DESAHUCIOS: CONEXIONES CINEMATOGRÁFICAS TRANSNACIONALES DE CRISIS EN EL PASADO Y EN EL PRESENTE

\section{RESUMEN}

Crisis es la palabra que mejor caracteriza la coyuntura del siglo xxi. El panorama inestable de un presente incierto y turbulento a menudo fomenta la proliferación de imágenes nostálgicas del pasado, convertidas en escenarios edulcorados de recuerdos escapistas. Por otro lado, las divisiones económicas, sociales y políticas del presente han puesto de manifiesto la necesidad de revisar ciertos aspectos históricos desde otras perspectivas. Este es el caso del cine de Gurinder Chadha que aboga por un cruce de fronteras culturales que muestra la naturaleza híbrida de las comunidades que representa y su origen. Siguiendo la metodología de Robert Stam que, desde un punto de vista fílmico y cultural, incluye un enfoque transdisciplinario, transmediatico, transtextual, transregional y transartístico (2019), analizaré la película El último Virrey de la India como una propuesta de revisión de la Partición de la India que ofrece una conexión transnacional e interseccional crítica de escenarios globales y locales contemporáneos.

Palabras Clave: crisis, recesión, cine de época, transnacional, nostalgia.

DOI: https://doi.org/10.25145/j.recaesin.2021.83.13

Revista Canaria de Estudios Ingleses, 83; November 2021, pp. 173-187; ISSN: e-2530-8335 
Gurinder Chadha's Viceroy's House was released the year when the $70^{\text {th }}$ anniversary of India's Independence and Partition was commemorated. 2017 was the UK-India year of culture, which celebrated a series of events that revisited the complex historical and cultural relationships between British and South Asian territories. The BBC broadcasted a special season of programmes 70 Years On: Partition Stories, which included documentaries produced by British-Asian filmmakers such as Anita Rani's My Family, Partition and Me: India 1947 and Chadha's India's Partition: The Forgotten Story, which showed the filmmaker's research on the historical events that were portrayed in her feature film Viceroy's House (70 Years On, 2017). India and Pakistan memorialised the event, yet the painful remembrance of Partition often cast a shadow over the celebrations of independence. ${ }^{1}$

Chadha's Viceroy's House was therefore released against a background of past remembrance and recovery. The willingness to revisit the past goes hand in hand with the increasing instability that the socio-economic processes of globalization entail. Situations of crisis fuel feelings of nostalgic harking back to times of yore which are perceived and imagined as more stable. The paradox of postmodern culture is that the yearning for revisiting the past is met with the impossibility of its full recovery (Rosenstone 2012). This situation has resulted in a neoliberal commodification of history and memory so that the generalised longing for the past becomes a profitable enterprise. A conspicuous example is the British heritage industry which boomed during the Thatcher decade (1979-1990). As part of this phenomenon, heritage and Raj Revival cinema spurred a nostalgic harking back to British imperial times. It is true that heritage cinema is associated with "the construction of a collective cultural memory" (Vidal 2012: 2) and that Raj revival films offered an orientalist vision of the Empire (Wollen 1991; Rushdie 1992). Nonetheless, these films also brought to the fore present-day tensions in terms of class, gender and race, which advocated for a kind of critical, revisionist nostalgia, and not mere escapism (Oliete-Aldea 2015).

The economic and social instability of the New Millennium fuelled a renewed harking back to imperial times in the UK and pro-Brexit discourses made the most of it. As Berghahn explains:

Not unlike in the Thatcher era, the heyday of the Raj revival films, it has been interpreted as a response to the gloom of austerity resulting in a weakening of national pride and self-confidence. Hence the rallying cry of the Brexiteers 'Britain will be great again' -as if leaving the EU would automatically give Britons the Empire back. (2019: 39)

* Research towards the writing of this article has been funded by the Aragonese Government, project no. H12, and the Spanish Ministry of Economy, Industry and Competitiveness, project no. FFI2017-82312-P.

1 Partition has been portrayed cinematically since the 1940 s, especially in films in Hindi, Bengali and Urdu, and by diaspora filmmakers. British Raj revival productions also tackled Partition in Gandhi (Attenborough 1982) and The Jewel in the Crown (ITV 1982), as well as in documentaries such as Partition: The Day India Burned (Pollack 2007). See Rini Bhattacharya Mehta and Debali Mookerjea-Leonard 2015 and Dwyer 2017. 
A romanticised 'Raj vintage' style could be appreciated in shops and decoration in restaurants. In cinema, Victoria and Abdul (Frears 2017), The Black Prince (Raz 2017), and productions such as Indian Summers (Channel 4 2015-16) -and implicitly, The Best Exotic Marigold Hotel (Madden 2011), The Second Best Exotic Marigold Hotel (Madden 2015)- are examples of the twenty-first-century Raj Revival. ${ }^{2}$ Yet, as occurred in the 1980s, some of those nostalgic films were critical re-visions of the past which also condemned some of the ills of the present conjuncture. Diaspora filmmakers in particular added a transnational turn by combining the 'heritage' filmic tradition with 'Bollywood crossover' cinema in order to utter subaltern voices which had hitherto been silenced. ${ }^{3}$ It is against this representational background that the film Viceroy's House puts to the test the current historical conjuncture, as well as the transhistorically and transculturally constructed artificial boundaries which impede to connect affective structures of feeling to the construction of history. Following Robert Stam's cultural and filmic methodology which includes a transdisciplinary, transmediatic, transtextual, transregional, and transartistic approach (2019), this article will explore Chadha's film as a revisionary text on India's Partition of 1947 which also offers a critical transnational and intersectional connection of contemporary global and local scenarios.

Partition epitomizes a moment of crisis which was aggravated by the British decision of bringing forward the date of independence so that they were not blamed for the political, social and economic havoc they had originated throughout colonisation of the Indian Sub-Continent. The term crisis refers to a particular moment of change, a turning point which entails a decision and course of action to tackle a problem and provide a solution (Kosseleck 2002). Runciman (2016) points at the discursive construction of the term "crisis" and the contingency of its duration, which depends on who experiences its effects. In this sense, India's independence marked the end of a crisis for the British and its aggravation in the former colonial territories.

The twenty-first century has also been characterized by a series of crises, starting with the $9 / 11$ terrorist attacks and war on terror in the US, followed up by the global financial crisis and Great Recession, which escalated in a series of austerity, political and democratic crises, and continued with environmental, refugee and health crises. All of them are intertwined and originated not at the very moment they were coined but some decades, even centuries, ago, with international impact. The concatenated nature of these events has been also described as a single organic and multifaceted crisis (Grossberg 2015). The convenient neoliberal motto "There is no alternative," linked the moment of crisis and the subsequent decisions to an

2 The chain of restaurants Dishoom and the that of luxury shops The East Indian Company the aesthetic 'experience' of the British Raj into a commodity to be consumed by twenty-first-century customers (Berghahn, 2019; Clini, 2019).

${ }^{3}$ Further analyses of "crossover cinema" and diaspora films and their subversive potential has been carried out by Desai (2000), Raminder and Sinha (2005), Dudrah (2012), Gehlawat (2010) and Diego Sánchez (2015). 
irreversible and irremediable path and therefore leaving vulnerable citizens hit by the crisis in a state of paralysis and inaction. ${ }^{4}$ Growing economic inequalities within and between countries, regions and supranational structures derived into authoritarian and protectionist movements blaming minorities for the precarious context.

The commemorative events of India's independence and the Partition crisis were therefore remembered in convulsive times at a global scale when both emancipatory and divisive movements were at stake. In a similar trend, Brexit 2016 referendum has built up a frontier which separates the UK from Europe but it has also revealed a polarized internal division among the British population within its own nations, regions, social classes and generations. Reminiscent of Thatcher's calls to "make Britain Great again," Brexit discourses promised to protect the UK borders from unfavourable European policies and from unwanted immigration. 2016 also witnessed Trump's presidential election with his motto "Make America Great again." These claims revealed profound scars in US society brought about by the President's controversial views on the economy, society, gender and ethnicity and his promise to build the wall in the US-Mexico frontier; walls which were also replicated in European frontiers to prevent the entrance of refugees and migrants. India was also experiencing further social division, as Modi's neoliberal policies were increasing the gap between the wealthy and the poor, at the same time that he advocated for Indian traditional values, fuelling nationalism and igniting further religious tensions. In September 2016, newspapers headlines in the international press showed concern about a possible war between the two countries as the Kashmir conflict escalated. The highly militarised Line of Control in Kashmir epitomizes the long-standing scar of Partition (Khan, 2017). ${ }^{5}$

These three examples have something in common: the idea that the construction of walls will protect a country from the ills of globalization, namely the free movement of migrants which are blamed for economic and social decay, while the neoliberal flows of financial capitalism boost. The idea of 'pure' imagined communities that imperialist nostalgia yearns for is counteracted by critical revisions of the past which reveal and celebrate the existence of hybridity in a past re-visited from the hitherto obliterated margins. Chadha's Viceroy's House is a conspicuous example of such reflexive nostalgia (Davies 1979). By revisiting an English Literary classic in Bride and Prejudice (2004) or producing a crossover heritage film in the Raj revival fashion, Chadha challenges the view of appropriation and heritage itself. Chadha's filmography could be thus labelled as transnational, understood as a method which points at the uneven nature of global movements and flows with their own temporal and spatial interdependencies (Stam 2019: 233).

4 The There is No Alternative (TINA) slogan was widely used by Margaret Thatcher during the 1980s and is still uttered by neoliberal governments whenever unpopular measures are to be imposed specially in times of crisis (Bauman, 2007).

5 Tension in the region recently escalated, resulting in the Revocation of the Special State of Jammu and Kashmir in August 2019. Since then, lockdown and curfews have been imposed to the region. 
The "transnational" has been defined as "the global forces that link people or institutions across nations" together with their critical responses (Ezra and Rowden 2006: 2-5) namely, what Higbee and Lim call "critical transnationalism" (2009). Chadha crosses borders by presenting characters turned into various imposed national allegiances and narratives that unfold not only the multicultural but also the hybrid nature of identity itself. Furthermore, her films result from intertwining different genres and cinematographic traditions. Such hybridity provides a critical transnational tool in terms of a cultural text that questions other hegemonic global accounts of past and present history and memory. Using Stam's terminology, Chadha's film is therefore a transtextual and transartistic product which also combines a transectional approach to the narrative events.

In line with other academic and cultural analyses of the past events in the "memory boom" context of the last decades (Winter 2007), Chadha's film aims at portraying India's Partition from perspectives other than those which had been provided by the official dominant discourses on the events. The film, though, was not exempt from criticism. Chadha was accused of portraying a negative view of Muslims while favouring not only the portrayal of Hindus but also the Viceroy himself (Bhutto 2017). She was also criticized for historical inaccuracies, basing her interpretation of the causes of Partition on unreliable resources (Jack 2017, Matthews 2017). Cinematically speaking, her film was accused of sweetening the portrayal of such cruel events as well as trying to include too many storylines in a single film, leading to a superficial portrayal of characters and events (Mullen 2017, Rees 2017). Chadha responded that she intended to make a film on reconciliation. In her own words,

I didn't want to make a film that recreated violence [.] I knew I didn't want to show women getting raped and jumping into wells, or Hindus and Muslims killing each other. I wanted to do something on these ordinary people that I had met, because it was so different from the political discourse." (in Grant 2017)

An in-depth analysis of the film actually reveals the subversive potential of such intertwined narratives from the perspective of "ordinary people."

The transtextual nature of the movie is revealed in its combination of generic conventions closely associated to well-known 'national' cinematographies with a transnational scope: the British heritage film and the 'Bollywood' romance and melodrama of Indian popular cinema. ${ }^{6}$ As a critical category within the umbrella term of "historical cinema," "heritage films" are intrinsically associated with British

${ }^{6}$ Indian popular cinema comprises a variety of local industries in the Indian Subcontinent, yet the term "Bollywood" became a cultural dominant popular signifier of Indian national cinema in Hindi, which acquired a transnational and Pan-Indian meaning (Mishra 2009). Aware of the contested meanings of the term Bollywood, I will use it in this essay to refer to mainstream popular Indian films with an often transnational distribution and scope. For a further discussion on the term, see Raminder and Sinha 2005, Gehlawat 2010. 
national cinema (Higson 2011, Vidal 2012). The careful mise-en-scène, beautiful landscapes, historic sites and buildings provide visual pleasure for spectators willing to nostalgically hark back to Britain's times of wealth and splendour. In the 1980s, such visual pleasures were enhanced with the exotic landscapes of the Raj revival films. Hence, Heat and Dust (Ivory 1983), Gandhi (Attenborugh 1982), A Passage to India, The Jewel in the Crown (ITV 1982) and The Far Pavilions (Channel Four 1984) were much criticized for fuelling imperialist nostalgia in the line of Thatcher's conservative discourses on British traditional values. British heritage was associated with whiteness and upper class standards, which were highlighted in the portrayal of aristocratic and upper middle-class lifestyle. Heritage and Raj films also contained critical views which contravened those hegemonic discourses and prevented spectators from indulging uncritically in the visual pleasures of the past. Tensions in terms of gender, class, ethnicity and national identity were portrayed as problematic not only in the past but also when read against the present time of their release (Oliete-Aldea 2015). These films, therefore, offered "reflexive nostalgia" which has been the case of subsequent (post)heritage productions in the 1990s and 2000s (Higson 2011; Vidal 2012).

Viceroy's House could be broadly labelled as historical drama. Nevertheless, the approach to the historical events is closer to the heritage tradition, as very much attention is paid to heritage sites and buildings with a careful mise-en-scène and detailed decoration. Another important feature in Chadha's film is the portrayal of an intimate, personal side of the main characters, in an attempt to present a "feminized" perspective and portrayal of what occurred inside the private sphere of such historical spaces while historical events unravelled in the outside (Vidal 2012; Oliete-Aldea 2015). The film thus follows the generic conventions of Raj Revival films in both providing visual pleasures of the past with India's exotic tinge yet offering also a critical revision of the events. The film starts with the epigraph: "History is written by the victors," 7 which renders account of the past with suspicion (0:01:06-0:01:09). Then, an establishing shot offers a panoramic view of the Viceroy's house at the background, indicating that the audience is invited to see Delhi in 1947. The camera moves inside the British quarters and shows the splendid gardens and magnificent rooms of the palace. We also see the Indian staff working in the house while supervised ultimately by their British masters, reproducing an ordered and hierarchical colonial structure. The camera pans over several portraits of former viceroys to stop in a picture of the last one (0:01:09-0:02:40). Heritage films have traditionally tended to focus on upperclass characters, yet Chadha's film introduces the working-class Indian characters first, since her intention was to provide an upstairs/downstairs perspective in the film, as in the Upstairs, Downstairs (ITV 1971-1975), Gosford Park (Altman 2001), or Downtown Abbey (Fellowes, ITV 2010-2015) (Walsh 2018, Gant 2017; Aftab 2017).

The film makes an intertextual reference to the latter by having Hugh Bonneville, Lord Chapman in Downton Abbey, playing the role of the Viceroy,

\footnotetext{
${ }^{7}$ Although attributed to Churchill, this expression actually has uncertain origins.
} 
allowing audiences to sympathize with this character. Lord Mountbatten is first introduced as a family man, exchanging views with his wife Edwina (Gillian Anderson) and his daughter Pamela (Lily Travers) about his mission as India's last Viceroy while traveling to the country by plane (0:06:22-0:07:20). Edwina's knowledge and opinions reveal that she is an active woman who is going to help actively her husband in his mission, the film thus allowing female characters to have a prominent role in the narrative. After that, the movie shows the pompous arrival of the Viceroy in India, with long shots displaying the ceremony as Lord Mountbatten and his family are taken in their carriage to the palace, where they are received by the former Viceroy and all the staff (0:07:20-0:09:10). The scene is similar to those of the Raj films of the 1980s, particularly A Passage to India (Lean 1984), which also shows the ceremonies welcoming the arrival of the Viceroy.

In these first images, the main building stands at the centre of the screen and will remain at the centre of the narrative. The images of the palace highlight symmetry and order. Every detail has been taken care of, all is clean, bright and employees work efficiently. Raj revival films generally depict the order of the spaces inhabited by the British, to be contrasted with the chaos of Indian streets and neighbourhoods. The arrival of the Viceroy in A Passage to India reflects this clear-cut contrast. Also, Attenborough's Gandhi and Morahan and O'Brien's The Jewel in the Crown display the peaceful houses of white British citizens living in the Raj as opposed to the chaos in the streets when independence is granted to the colony. Chadha's film also provides that contrast between the first and last scenes of the feature. However, the narrative clearly blames the chaos of the denouement to the British divide and rule policy as well as their rush to leave the country due to political interests, rather than making Indian culture responsible for their lack of ability to self-rule. Chadha carefully portrays tolerance among the different ethnic and religious groups, which is clearly disturbed by the decisions taken by British and also Indian politicians. The spaces inhabited by Indians, such as the employees' quarters, are shown to be humble and poorer, but also clean and cosy, highlighting the peaceful conviviality of its residents -only to be altered by the tense conflict of the imminent partition.

Instead of portraying the historic events from the point of view of the British, as Raj revival productions did, Chadha balances the perspective by including that of the Indians, allowing them to have the status of main characters. Nonetheless, as in many other heritage productions, the building itself, which provides the title to the movie, is actually the main character. Similarly to Brideshead Revisited (ITV 1981), Howards' End (Ivory 1992), and Downton Abbey, the question of who is going to inherit and inhabit the house, together with the matter of its own survival, is the main issue at stake in the narratives. The plot usually revolves around the potential inheritors of a particular estate and the traditional values associated to it, which are often questioned in terms of gender and class. The buildings stand still while convulsive changes in history threaten their survival together with the traditional values attached to them. The transformation of the Viceroy's House into Rashtrapati Bhavan, home of the President of India, symbolically lies at the centre of the narrative. Ironically, the building itself was conceived as a hybrid construction. Designed by British architects to be home of the Viceroy in Delhi, its architecture blends 
European neoclassical and Mughal styles both in the structure, inner decoration and its surrounding gardens. The building is not purely Indian, nor entirely British. Identity is shown to be contingent to political interests, which favour the creation and transformation of nations depending on the geopolitical interests of those who hold more power. National allegiances towards India as a nation are shifted into religious ones, which are, in turn, merged with a new form of nationalism with the creation of a newly shaped India, Pakistan, and, later on, Bangladesh.

As explained above, the film first shows the Indian employees within the palace's premises. It will be in subsequent scenes that Lord Mountbatten will arrive in, taking up his position as Viceroy and therefore his right to inhabit the place. His arrival, however, is portrayed as if he were actually stepping in a space which does not belong to him but to the vast amount of its workers. The camera shows his entrance to the building from above, taking the perspective of Aalia Noor (Huma Kureshi) -assistant to the Viceroy's daughter Pamela- who is standing in the upper galleries, together with other members of the staff (0:08:45-0:09:10). In spite of the hierarchy and power granted to the British, the high angle shot of the Viceroy from above surrounded by all the Indian staff is quite intimidating, rather questioning the entrance of the Viceroy to that space as an 'invasion.' This is particularly relevant in a (post)colonial context, since, according to Nirmal Puwar, spaces are not fixed but dynamic entities (2004). Colonial land was appropriated by the colonisers and the right to abode in certain spaces was suddenly forbidden to certain racialised and gendered identities. Puwar points out that it is not only a matter of the legal right to occupy a space, but also how certain individuals are perceived as "space invaders" in certain locations (2004). This scene, thus, represents the way British authorities are perceived as invading those spaces in British India which had hitherto been occupied by them and forbidden to Indians themselves.

This feeling is reinforced by a previous scene, which shows the arrival of Jeet Kumar (Manish Dayal) to the place as the new Viceroy's valet. He is guided through the rooms and corridors by his cousin; with the camera closer to him, he is shown to be integrated in the space. Jeet claims that he imagines England as this palace. His cousin replies that England is now ruined by the war, that is why the British can no longer afford to maintain an empire and are thus leaving India (0:03:130:03:40). This conversation is very telling, as it questions the idea of postcolonial indebtedness. According to Robert Stam, Eurocentric perspectives, understood in ideological rather than geographical terms, have constructed the Global North as creditor and the Global South as debtor, as if European/Western 'progress' were autonomous, disregarding the wealth and resources that came and still come from (formerly) colonized regions, namely the "Four Cheaps: labor, food, energy and raw materials" (7). The film thus questions the structures of power not only during the times of the Raj but also after its demise, since the very act of independence and partition is eventually revealed to work in the interests of the West/North.

The film shows the terrible consequences of 1947 Partition for the Indian -and soon-to-be Pakistani- population, namely those 'ordinary people' who suddenly realised that their own homes belonged to a country which was suddenly hostile to their religious beliefs. Paradoxically, instead of regaining the rights to 
the land and resources which had been usurped by the colonial rule, many people found themselves displaced and evicted from their own houses. Symbolically, the images of refugees crossing the new national borders are combined with the absurd distribution of the Viceroy's House assets between the two countries, such as the volumes of the encyclopaedia, cutlery and a random distribution of the canon of British literature. By portraying the Viceroy's House change of occupier, the film actually depicts a massive eviction. The film devotes no scene to the Viceroy and his family abandoning the house, as their privileged position will never leave them homeless. In contrast, there are several shots of the Indian staff having to choose allegiances between India and Pakistan, many of them having to change residence forcefully and dangerously, without any specific point of arrival.

The image of an empty house and homeless people recalls some of the twenty-first century crises: the mortgage-economic crisis, leaving many people homeless, often affected by long-term unemployment and thus forming part of an underclass. It also brings to mind the refugee crisis seen on Italian or Spanish shores, with many migrants fleeing the terrible economic conditions and violence in their countries, just to find more violence in the borders which prevent their entrance. The film also connects the contingency of the Partition crisis with the twenty-first century multifaceted crisis: the vulnerability of people whose lives are suddenly affected by the decisions of those in power. The gap between the powerful and the powerless, the rich and the poor, which can be appreciated in 1947 India-Pakistan, is also patent 70 years afterwards, with the existence of a powerful transnational overclass and a vulnerable transnational precariat (Bauman 2007; Standing 2016). The scenes portraying British and Indian politicians arguing about the situation in their glamorous parties and ostentatious offices and rooms are contrasted with the poverty and violence lived by common people in the streets. A parallel situation could be established between these sequences and the cinema of the financial crisis, which portrayed bankers and politicians discussing about the dilemma of bailing out the banks in their luxurious skyscrapers while more and more people became unemployed and homeless. Eviction, precarity and vulnerability have become recurrent tropes in the cinema of the New Millennium. ${ }^{8}$ This cinematic link in terms of narrative and imagery reveals not only postcolonial legacies but also the intersectionality of race, gender and class issues across time and space.

The aesthetic conventions of heritage cinema in Chadha's film include intertextual references to other Raj revival movies. Cinematic productions such as Attenborough's Gandhi and the series The Jewel in the Crown depicted a realist, documentary-style aesthetic -close to the British tradition of filmmaking-which included newsreel footage of the times combined with fake newsreels with the movie actors. Chadha makes use of the same techniques when referring to the historical

${ }^{8}$ Examples of the contraposition of the privileged overclass and the precariat include financial crisis films, such as Freefall (Savage 2009), and austerity cinema with movies such as I Daniel Blake (Loach 2016). See Oliete-Aldea 2018. 
events present in the film. Apart from that, the transartistic contraposition of Chadha's film and her documentary, India's Partition: The Forgotten Story (2017) intends to justify the evens narrated in the film and therefore respond to the accusations of fake history and unreliability that the film got after its release. The film offers an interpretation on Partition which refers to a document elaborated by Winston Churchill as a plan on the part of the British to grant a territory to Jinnah so that India -and its soviet sympathies-could be weakened and access to a seaport with an ally state in the area could be granted. Even though it is true that the documentary fails to provide proof that this document actually existed, it nonetheless acknowledges the feasibility of that explanation. Rather than enlightening the spectator with an epiphany of hitherto hidden true events, both film and documentary leave the audience with questions which put to the test previous accounts of the past whose cinematic truths are taken for granted. Chadha, therefore, aims at portraying other histories which have not been written by the victors.

This re-writing of history from the margins not only considers a silenced and marginal perspective in terms of ethnicity and national identity, but also in terms of gender. Heritage and Raj Revival films offered a "domestic" and "feminized" view of history which contributed to the critical tone of such "reflexive nostalgia" (OlieteAldea, 2015). Chadha enhances the female perspective by giving a prominent role to Edwina Mountbatten, emphasizing her concern for implementing measures that intended to promote the conviviality and understanding among Britons and Indians. As opposed to her husband's focus on external appearance and ceremonies, she tries to give advice on practical matters and takes the initiative in inviting the wives of princes and politicians to their events and parties. As a character constructed in a film released within the context of the fourth-wave feminism, Edwina symbolically stands for a feminized vision of history and society which cares for the well-being of ordinary people and prioritises reconciliation and conviviality over political and individual interests. Her decision-making power, however, is limited to the private sphere, and she is shown to unwillingly support her husband's views on Partition and has to leave the room in which negotiations are taken by male politicians. Similarly, Aalia is portrayed as a strong and independent Muslim Indian woman, features that contradict the often represented stereotype of the submissive Oriental woman (Oliete-Aldea 2015). She is torn between her family duty and her individual choice of husband, yet it is the turbulence of 1947 Partition that makes her sacrifice her wishes for her father's safety. Becoming a victim of violence, she represents the suffering of women during Partition; nonetheless, she is also depicted as a survivor, being rescued by another woman and actively taking the microphone and shouting Jeet's name so that both of them can finally meet in the refugee camp.

The British restrained and realist mode of filmmaking of heritage cinema is combined with the generic conventions of fantasy and melodrama of Indian popular cinema, thus highlighting the artificiality of any filmic recreation of the past. The transnational mixture of generic conventions highlights the hybridity of Chadha's filmmaking style. The bright and warm colours of the scenes deviate from the realist shooting of British cinema, while the conventions of mainstream Indian movies are foregrounded with the melodramatic denouement. The troubled inter-religious 
romantic relationship of the main characters and a daughter's duty to comply with an arranged marriage against her will are recurrent plot stories in Bollywood dramas. ${ }^{9}$ The irruption of the melodramatic conventions of Bollywood cinema thus undermines restrained British filmmaking style in favour of the screen portrayal of feelings and emotions. The importance of emotion derives from the concept bhavarasa and is fundamental in Indian aesthetic theory. ${ }^{10}$ As Mishra explains:

Rasa as a theory of embodiment is based on connecting to an audience through evoking a collective emotion. It is a theory of communication that shows that human expressivity and subjectivity are shaped and shared in relationships with one another and to the material world. (2009: 215)

Emotions are connected to human subjectivity and spirituality and often expressed through music and dance. In classical Indian performing arts, the dramatist, through art, should convert an emotion (bhava) into rasa, which would transform the aesthetic experience of sensitive spectators. Ultimately, the experience of rasa requires empathy on the part of the spectator, who will transcend from a self-centred perception of the individual (Higgins 2007). The use of rasa as shared structures of emotion could be related to Raymond Williams "isomorphic structures of feeling," which, in transnational cinema, acquire a relevant status. According to Stam, "isomorphic structures of oppression and identification provoke affective bonds and link similar movements across borders" (149). The emotions arisen by the situations described in Chadha's film may not only appeal to victims of Partition in both the Indian Sub-continent and in diasporic communities around the globe, but may also recall the suffering of global audiences, which resonates in the present caused by policies of division: mass migrations and house evictions. As mentioned above, Chadha refused to depict the violence exerted on refugees trying to reach the other side of the newly created borders. The movie focuses, instead, on the emotions of pain and suffering felt by the main characters in their separation and final re-union to reach the spectators' compassion with a Muslim woman and a Hindu man, by sharing their pain collectively as part of a multicultural audience. The objective of the film is thus to utter those traumatic unspeakable silences by depicting situations that convey shared emotions by an eclectic audience.

Music and dance are essential elements in Indian popular cinema which contribute to express hidden or suppressed feelings and emotions. Chadha includes a dance sequence which hints at Bollywood cinema (0:24:46-0:29:15). In the staff quarters, people from different geographical and religious origins party together until there is a confrontation between Hindus and Muslims due to the heated sociopolitical situation. Characters are finally reconciled and both Aalia and Jeet dance together enjoying a brief moment of happiness that is soon going to come to an end.

9 Veer-Zaara (Chopra 2004) is a conspicuous example.

10 The origins of the concept can be traced back to Bharata's Natyasastra, a "manual" on technical knowledge about the performing arts (200-500 CE) (see Higgins 2007). 
The party is embedded in a quotidian situation, expressing the spontaneous festivities of downstairs staff, as opposed to the formal parties of the British and upper-class Indians. The dance sequence therefore unifies cinematically both the British heritage and Bollywood traditions. On the one hand, it works as a way to convey rasa as happiness in aesthetic beauty, elevating spiritually the spectator beyond class, gender, race and religious divisions, with love as the ultimate expression of happiness in unity. It represents the fantasy of peaceful cohabitation and a Gandhian unifying vision of India. On the other hand, it celebrates freedom and natural cohabiting of people when released from social norms orchestrated by the British divide-and-rule policy in colonialism, which replicates the rigid class system in British society, too. While dance sequences of the upper classes show a choreographed rigidity of social norms, working class dance and music tends to be more spontaneous and enjoyable, a space when characters can be freed up from social constrains. ${ }^{11}$

The dance sequence, therefore, epitomizes Crenshaw's concept of "intersectionality:" "the ways in which the various axes of social stratification-class, gender, race, sexuality and so forth are interconnected and mutually impacting" (in Stam 139). According to Stam, a transnational approach could add a further dimension to the meanings these axes might represent as common transnational phenomena with their own local inflections. When taking into consideration the emotional attachment to the situations experienced by individuals and communities affected by such axes, minorities may identify transnationally with other groups due to their own affinities. In this sense, Chadha's film acquires a further dimension when analysed in the cultural conjuncture of the time of its release. Apart from sharing the specific historical collective trauma of Partition, the film also interpellates the contemporary transnational audience to share collective structures of feeling in the current postcolonial context of the film release.

Further emotions are expressed in the final scene (1:31:41-1:35:22). The intense, far-fetched ending sacrifices a realistic plot in favour of the symbolic union of the Hindu-Muslim couple amidst religious hatred. This bitter-sweet, weepy ending seems to provide an intertextual hint at Bollywood cinema yet, when read against the ending credits, it acquires a further meaning. The filmmaker portrays pictures of real people who suffered situations similar to those of the characters in the movie, only to unveil that one of those women was her own grandmother (1:35:42-1:36:32). This ending foregrounds the importance of individual and collective memory, which goes hand-in-hand with historical events. It emphasizes the importance of recognizing the pain that has been silenced for decades, and the need to represent

11 Examples of characters being freed up by dance can be found in The Jewel in the Crown, with the interethnic couple dancing together (Oliete-Aldea 2015: 185-186). More recently, Downton Abbey also offers a contraposition of characters finding their true expression of their identities and relationships in popular dance sequences as opposed to rigid upper class ballroom conventions. Other well-known examples are Titanic (Cameron 1997) in Hollywood and Kabhi Khushi Kabhie Gham (Johar 2001) in Bollywood. 
and acknowledge individual and collective traumas in order to be able to heal those wounds or, at least, to understand the traumatic scars of the present.

By combining different filmic traditions in a transnational film, Chadha creates a hybrid outcome which questions the authenticity of any screen recreation of the past in terms of telling the truth of historical events. As Hayden White states, any recreation of the past entails a selection and interpretation of the events, which will be encoded and decoded following literary or, in this case, cinematic codes (1990: 47-48). Memory, as well as history, acquires a conspicuous status, as it does not entail a mere recreation of the past but brings to the fore the importance of disclosing the feelings attached to remembrance. This is what the conventions of Bollywood melodrama add to the film: the importance of acknowledging the suffering of collective trauma which has not yet been overcome. As any faithful portrayal to historical events can be questioned, the filmmaker does manage to be faithful to her relatives' suffering by foregrounding the relevance of depicting and re-living the traumatic emotions experienced in the past so that they can be recognised and shared collectively by the audience.

Historian Yasmin Khan (2017) highlights the importance of understanding that Partition occurred in a complex socio-political conjuncture and that many documents which could explain its causes were lost or destroyed. As difficult as it is blaming any side for its outcome, what can be done is to analyse its consequences for all the parties involved. It is actually crucial to link the historical events with the memories of victims and survivors, as well as with the sociological accounts of the contemporary conjuncture. In Khan's words: "The rendering of Partition as a uniquely devastating event works to place it beyond the bounds of comparative accounts and, perhaps, to silence its echoes in contemporary global politics" (XXXIII). Viceroy's House is a film which tackles history and memory by establishing a dialogue between central and marginal accounts of the past. It depicts how the independence of a colony was transformed into a devastating crisis to favour the interests of a transnational overclass, symbolically protected in the magnificent palace. The rush in the decision-taking process and its disastrous consequences for ordinary people cannot but recall the contemporary conjuncture in which the film was released: the construction of real and metaphorical borders which leave a transnational precariat in highly vulnerable situations. As a diaspora filmmaker, Chadha has created a cinematic universe in which hybridity stands for the subversive potential of hope that may shake those dividing walls (Diego Sánchez 2015). Viceroy's House does not unveil hidden truths nor does it offer a faithful re-creation of hitherto distorted events. It just adds a new perspective which combines history and memory as well as different cinematic traditions in order to be faithful to the stories or ordinary people in a transnational and transectional masala film.

Review sent to author: 07/05/2021

Revised version accepted for publication: 28/06/2021 


\section{WORKS CITED}

“70 Years On: Partition Stories.” BBC (2017). https://www.bbc.co.uk/programmes/p05b5fdg. (Last accessed 15 March 2021).

Aғтав, Kaleem. "Director Gurinder Chadha on the inspiration behind the historical drama Viceroy's House.” The National (2017) https:/www.thenationalnews.com/arts-culture/ director-gurinder-chadha-on-the-inspiration-behind-historical-drama-viceroy-s-house1.84897? videoId $=5587698090001$. (Last accessed 3 May 2021).

Bauman, Zygmunt. Liquid Fear. Polity Press, 2007.

Berghanhn, Daniela. "The past is a foreign country': exoticism and nostalgia in contemporary transnational cinema." Transnational Screens 10/1 (2019): 34-52. https://doi.org/10.1080 /25785273.2019.1599581.

Bhutro, Fatima. "Fatima Bhutto on Indian Partition Film Viceroy's House: 'I watched this servile pantomime and wept.” The Guardian (3 March 2017). https://www.theguardian.com/ film/2017/mar/03/fatima-bhutto-viceroys-house-watched-servile-pantomime-and-wept. (Last accessed 02 April 2021).

Chadha, Gurinder. 2017. "Gurinder Chadha: My film has been wilfully misrepresented as anti-Muslim.” The Guardian. (3 March 2017). https://www.theguardian.com/film/ filmblog/2017/mar/03/gurinder-chadha-defends-viceroys-house-film-fatima-bhutto. (Last accessed 02 April 2021).

Clini, Clelia "Diasporic visions: colonialism, nostalgia and the empire in Gurinder Chadha's Viceroy's House." South Asian Diaspora 13/1 (2020): 23-36. https://doi.org/10.1080/19438192.202 0.1767894 .

Diego SÁnchez, Jorge. "Educational Attainment in the South Asian Diaspora: Representation of Gender Conflicts in Gurinder Chadha and Mira Nair Films." Raudem 3 (2015): 117-135.

Dwyer, Rachel. "Partition in Hindi Cinema: Violence, Loss and Remembrance." 2017. https:// thewire.in/film/partition-hindi-cinema. (Last accessed 02 April 2021).

Dudrah, Rajinder. Bollywood Travels: Culture, Diaspora and Border Crossings in Popular Hindi Cinema. Routledge, 2012.

Ezra, Elizabeth \& Terry Rowden. Transnational cinema: The film reader. Routledge, 2009.

Gant, Charles. "Viceroy's House." Sight and Sound 27/3 (2017): 14-15.

Gehlawat. Ajay. Theories of Popular Hindi Cinema. Sage, 2010.

Grossberg, Lawrence. We All Want to Change the World. Lawrence \& Wishart, 2015.

Higbee, Will, \& Song Hwee Lim. "Concepts of transnational cinema: Towards a critical transnationalism in film studies." Transnational Cinemas 1/1 (2010): 7.

Higgins, Kathleen Marie. "An Alchemy of Emotion: Rasa and Aesthetic Breakthroughs.” Journal of Aesthetics and Art Criticism 65 (2007): 43-54.

Higson, Andrew. Film England. Culturally English Filmmaking since the 1990s. I.B. Tauris, 2011.

JACK, Ian. "The Viceroy's House version of India's partition brings fake history to screen." The Guardian (18 March 2017). https://www.theguardian.com/commentisfree/2017/mar/18/ the-viceroys-house-version-of-indias-partition-brings-fake-history-to-screen. (Last accessed 5 March 2021). 
Kaur, Raminder \& Ajay J. Sinha, Eds. Bollyworld. Popular Indian Cinema through a Transnational Lens. Sage, 2005.

Khan, Yasmin. The Great Partition. Yale University Press, 2017 [2007].

Kosselleck, Reinhart. The Practice of Conceptual History: Timing History, Spacing Concepts. Stanford UP, 2002.

Matthews, Roderick, “Viceroy's House: Ghost House of History.” Open (2017). https://openthemagazine.com/essay/viceroys-house-ghost-house-of-history/. (Last accessed 5 March 2021).

Menta, Rini Bhattacharya \& Debali Mookerjea-Leonard. The Indian Partition in Literature and Films. History, Politics, and Aesthetics. Routledge, 2015.

Mishra, Vijay. "Spectres of Sentimentality: The Bollywood Film." Textual Practice 23/3 (2009): 439-462.

Mullen, Lisa. "Viceroy's House." Sight and Sound 27/4 (2017): 94.

Oliete-Aldea, Elena. Hybrid Heritage on Screen. The "Raj Revival" in the Thatcher Era. Palgrave, 2015.

Oliete-Aldea, Elena. "Global Financial Crisis in Local Filmic Scenarios: Transnational Cinema of the Great Recession.” Global Finance on Screen. From Wall Street to Side Street. Ed. Constantin Parvulescu. Routledge, 2018. 179-197.

Puwar, Nirmal. Space Invaders. Race, Gender and Bodies Out of Place. Berg, 2004.

ReEs, Jasper. “Cinema: Viceroy's House.” The Spectator (4 March 2017). https://www.spectator.co.uk/ article/parting-shots. (Last accessed 02 April 2021).

Rosentone, Robert. History on Film/Film on History. Routledge, 2012 [2006].

Runciman, David. "What Time Frame Makes Sense for Thinking about Crises?" Critical Theories of Crisis in Europe From Weimar to the Euro. Eds. P. Kjaer \& N. Olsen. Rowan and Littlefield, 2016. 3-16.

Rushdie, Salman. Imaginary Homelands. Essays and Criticism 1981-1991. Penguin, 1992 [1991].

Stam, Robert. World Literature, Transnational Cinema and Global Media. Towards a Transartistic Commons. Routledge, 2019.

Standing, Guy. The Precariat. Bloomsbury, 2016[2011].

Vidal, Belén. Heritage Film. Nation, Genre and Representation. Wallflower, 2012.

Winter, Jay. "The Generation of Memory: Reflections on the 'Memory Boom' in Contemporary Historical Studies." Archives \& Social Studies: A Journal of Interdisciplinary Research 1 (2007): 363-397.

Wollen, Tana. "Over our Shoulders: Nostalgic Screen Fictions for the 1980s.” Enterprise and Heritage: Crosscurrents of National Culture. Eds. John Corner \& Sylvia Harvey. Routledge, 1991. 178-193. 
